\title{
Duration of Seeded Stands on Terraced Mountain Lands, Davis County, Utah
}

\section{A. C. HULL, JR.}

Highlight: Thirty-seven species were seeded experimentally in northern Utah on 14 areas on depleted and terraced mountainous rangelands from 1936 to 1939. Seventeen species had fair to excellent 3-year-old stands. Most stands decreased; and in 1971 only smooth brome, tall oatgrass, intermediate wheatgrass, and red fescue have fair to excellent stands. Smooth brome spread slowly by rhizomes and usually formed a dense sod. Tall oatgrass spread by seed with a poor to good stand on ten times the original seeded area. Intermediate wheatgrass has spread by rhizomes and forms a good stand on the large plot where it was seeded in 1941. Red fescue did well on favorable sites but was not tested under typical conditions. Native grasses, forbs, shrubs, and trees have reinvaded the seeded areas.

Davis County, in northern Utah, was much in the news from 1923 to 1930 because of floods which took six lives and caused more than $\$ 1$ million damage (Marston, 1958). The 1930 Flood Com-

The author is range scientist, Agricultural Research Service, U. S. Department of Agriculture at Logan, Utah.

This paper was produced through the cooperative investigations of Agricultural Research Service and Forest Service, U. S. Dep. Agr.; and Utah Agricultural Experiment Station, Logan, Utah. (Utah Agr. Exp. Sta. Jour. Paper 1231.)

Seeding studies were initiated and conducted until 1954 by the Forest Service. At that time, responsibility for seeding research for domestic livestock on rangelands was transferred to Agr. Res. Serv. The author was formerly with the Forest Service and did much of the early work.

The author thanks personnel of the Forest Service and Agr. Res. Serv, who assisted with these studies. Special thanks to Grant Harris, Richard Hurd, W. M. Johnson, G. J. Klomp, C. K. Pearse, Henry E. Peterson, and R. H. Walker, who participated in the early work. Manuscript received February 16,1972 . mission concluded that depletion of plant cover by grazing and fire was the primary cause of flooding (Cannon et al., 1931;

From 1933 to 1939 , about 1,300 acres of high-elevation flood-source lands in Davis County were contour-trenched and seeded. The earliest seedings were in 1934, when all terraces constructed during 1933 and 1934 wcre fall-sceded to a mixture of four cultivated grasses and to some native species gathered in the area. Beginning in 1935, terraces constructed each year were seeded to mixtures of perennial grasses and rye ${ }^{1}$ in the fall of each year. Seeds were broadcast at 30 lb./acre, and the ground surface was brushed or raked to cover the seed.

All seedings produced good initial

${ }^{1}$ Scientific names of most species mentioned are listed in Table 1 . Bailey et al., 1934.) stands, but early records are lacking. Observations in 1936 and 1937 showed poor to fair stands of smooth brome, slender wheatgrass, rye, and horsemint on these early seedings.

To determine species for seeding these depleted and terraced mountain lands, experimental seedings were made from 1936 to 1939 . This is a report on the 32to 35 -year-old stands that resulted from these seedings.

\section{Procedures}

Seeded areas were depleted and usually supported only sparse, weedy vegetation such as tarweed (Madia glomerata), knotweed (Polygonum sp.), and coneflower (Rudbeckia occidentalis). Surrounding vegetation was mainly alpine fir (Abies lasiocarpa), aspen (Populus tremuloides), big sagebrush (Artemisia tridentata), snowberry (Symphoricarpos oreophilus), slender wheatgrass, columbia and letterman needlegrasses, geranium (Geranium viscossissimum), and other plants of minor importance.

Seeded areas ranged from 7,400 to over $9,000 \mathrm{ft}$ elevation, with most being about $8,000 \mathrm{ft}$. Most areas sloped south, west, or east with some slopes over $70 \%$. Annual precipitation is about 30 inches at the lowest seeded area and over 45 inches at the highest. 
We made 14 experimental seedings from 1936 to 1939. Seedings were mostly in the Parrish, Ford, Davis, Steed, and Farmington Creek drainages. Seeded areas had been terraced as described by Bailey and Croft (1937). Plots are irregularly shaped along the contour terraces. They extend up and down the slope from the crest of one terrace to the crest of the next. This width varies from 12 to $50 \mathrm{ft}$ and averages about $25 \mathrm{ft}$. Along the slope, plots occupy part of or all the length of a single terrace. Plot length varies from 20 to $280 \mathrm{ft}$ and averages about $100 \mathrm{ft}$. The amount of seed sown was adjusted to the size of the plot.

Thirty-seven species were tested, with 4 to 20 species in each of 14 studies. Seeding rate was at 12 to $20 \mathrm{lb}$./acre for species such as smooth brome and tall oatgrass. Rates for smaller seeded species were reduced about 25\%. Mountain brome was sceded at 15 to 25 and rye at 20 to $40 \mathrm{lb}$./acre. There were from one to three replications of each species within each study. Table 1 lists species used with the number of plots of each.

We seeded some study areas in the spring and some in early or late fall. Spring seedings were made in May or June, just as snow melted from the area. This often necessitated using horses to get to areas when roads were still covered with snowdrifts. Early fall seedings were made in late August or early September; late fall seedings occurred in October. In three areas we seeded in early fall, late fall, and in the spring; in one area we seeded in early fall and in the spring. As stands for each season of seeding were similar, they are averaged for each of the four studies.
Table 1. Species seeded, number of areas and plots, and ratings of 37 species about 3 years af ter seeding and in 1971. Davis County. Ratings are 10 to 0 with 10 being a full stand of grass.

\begin{tabular}{|c|c|c|c|c|}
\hline \multirow{2}{*}{ Species } & \multirow{2}{*}{$\begin{array}{c}\text { Areas } \\
\text { seeded }\end{array}$} & \multirow{2}{*}{$\begin{array}{l}\text { Number } \\
\text { of plots }\end{array}$} & \multicolumn{2}{|c|}{ Average ratings } \\
\hline & & & $1938-43$ & 1971 \\
\hline \multicolumn{5}{|l|}{ GRASSES } \\
\hline Bluegrass, Canada (Poa compressa) & 4 & 10 & 1.2 & .2 \\
\hline Bluegrass, bulbous (Poa bulbosa) & 4 & 10 & .3 & 0 \\
\hline Bluegrass, Kentucky (Poa pratensis) & 4 & 10 & 3.2 & .3 \\
\hline Brome, mountain (Bromus carinatus) & 11 & 31 & 4.7 & $.1^{\mathrm{a}}$ \\
\hline Brome, smooth (Bromus inermis) & 13 & 37 & 5.0 & 5.2 \\
\hline Canarygrass, reed (Phalaris arundinacea) & 7 & 16 & 4.1 & .6 \\
\hline Fescue, meadow (Festuca elatior) & 7 & 16 & 4.0 & 0 \\
\hline Fescue, red (Festuca rubra) & 2 & 3 & 3.7 & 8.3 \\
\hline Fescue, sheep (Festuca ovina) & 8 & 19 & 4.0 & .2 \\
\hline Fescue, spike (Hesperochloa kingii) & 2 & 4 & 4.3 & 1.3 \\
\hline Needlegrass, Columbia (Stipa columbiana) & 3 & 10 & 5.3 & $1.0^{\mathrm{a}}$ \\
\hline Needlegrass, letterman (Stipa lettermanni) & 2 & 4 & 6.5 & $1.0^{\mathrm{a}}$ \\
\hline Oatgrass, tall (Arrhenatherum elatius) & 12 & 32 & 4.2 & 4.4 \\
\hline Orchardgrass (Dactylis glomerata) & 5 & 15 & 3.1 & .7 \\
\hline Red top (Agrostis alba) & 4 & 10 & 6.7 & .2 \\
\hline Rye (Secale cereale) & 6 & 14 & 4.0 & 0 \\
\hline Ryegrass, perennial (Lolium perenne) & 7 & 16 & 2.3 & 0 \\
\hline Timothy (Phleum pratense) & 5 & 13 & 5.2 & .5 \\
\hline \multicolumn{5}{|l|}{ Wheatgrass, bearded (Agropyron } \\
\hline subsecundum) & 3 & 10 & 2.4 & 0 \\
\hline \multicolumn{5}{|l|}{ Wheatgrass, bluebunch and beardless } \\
\hline (Agropyron spicatum and $A$. inerme) & 2 & 8 & 1.4 & .1 \\
\hline Wheatgrass, crested (Agropyron desertorum) & 8 & 24 & 3.6 & .7 \\
\hline \multicolumn{5}{|l|}{ Wheatgrass, slender (Agropyron } \\
\hline trachycaulum) & 12 & 34 & 5.6 & $1.0^{\mathrm{a}}$ \\
\hline Wheatgrass, western (Agropyron smithii) & 7 & 17 & 2.6 & .1 \\
\hline Wildrye, blue (Elymus glaucus) & 3 & 10 & 5.0 & 0 \\
\hline Wildrye, Canada (Elymus canadensis) & 2 & 8 & 3.9 & 0 \\
\hline \multicolumn{5}{|l|}{ LEGUMES } \\
\hline Alfalfa (Medicago sativa) & 6 & 14 & 1.7 & 0 \\
\hline Clover, white (Trifolium repens) & 3 & 9 & 0 & 0 \\
\hline Lupine, ornate (Lupinus ornatus) & 1 & 2 & .5 & 0 \\
\hline Lupine, tailcup (L. caudatus) & 1 & 2 & 2.5 & 0 \\
\hline Sweetclover, white (Melilotus alba) & 1 & 2 & 0 & 0 \\
\hline Sweetclover, yellow (M. officinalis) & 3 & 10 & 3.3 & .3 \\
\hline \multicolumn{5}{|l|}{ ORBS } \\
\hline Goldeneye, showy (Viguiera multiflora) & 2 & 4 & 3.8 & 0 \\
\hline Groundsel, butterweed (Senecio serra) & 1 & 2 & 0 & 0 \\
\hline Horsemint (Agastache urticifolia) & 2 & 4 & 6.8 & .1 \\
\hline Ligusticum, Porter (Ligusticum porteri) & 1 & 2 & 4.0 & 0 \\
\hline Sunflower, little (Helianthella uniflora) & 1 & 2 & 2.5 & 0 \\
\hline Yarrow, western (Achillea, lanulosa) & 2 & 4 & 7.0 & .8 \\
\hline
\end{tabular}

aprobably native.
Seeds were broadcast by hand on the loose soil of the newly-constructed terraces or, in the case of spring seeding, on terraces constructed the previous summer. Seed was covered by raking with garden rakes. On hard soil or on undisturbed soil between the terraces, rake-like hand diggers were used to loosen the soil and cover the seeds.

For 3 to 5 years following seeding, notes were made on seeding success, and the stands were rated. Ratings were again made in 1966 and 1971. Ratings range from 10 to 0 , with 10 being a full stand of seeded grass. In 1938 we obtained yields by clipping the grass mixture on 36 $1-\mathrm{ft}^{2}$ samples per area. In 1971 we clipped ten $4.8-\mathrm{ft}^{2}$ samples of each seeded or native grass sampled on each area. In both years the samples were from areas judged to have a good stand of grass.

\section{Results}

The loose soil provided seed covering, and good seedling stands followed most seedings. Seventeen of the 37 species had stands which rated 4 (fair) or better 3 years after seeding (Table 1). Stands of most species deteriorated over the 32 to 35-year period, and by 1971 only three species (smooth brome, tall oatgrass, and red fescue) had stands which exceeded 4. From 1939 to 1971, stands of smooth brome on 37 plots increased on 16, decreased on 12 , and remained the same on nine plots. On 32 plots, tall oatgrass increased on 11 , decreased on 15 , and remained the same on six. Red fescue increased on all three plots. However, fescue plots were on partially-shaded, moist, favorable sites and were not typical of the seeded areas.

Intermediate wheatgrass (Agropyron intermedium) was seeded in 1941 in a larger planting adjacent to experimental seedings in Farmington Canyon. This species has spread rapidly by rhizomes and has a good stand of vigorous plants over the seeded area. Seedings in other areas show that this grass is well adapted to many mountainous ranges. Reed canarygrass failed on dry sites, but it produced dense stands and spread in gullies and moist places wherever it was seeded. This species should be considered for seeding such sites.

The growth habits and spread of smooth brome and tall oatgrass are different. Smooth brome has spread slowly, mainly by rhizomes, and has formed a good sod to the exclusion of most other species. On harsh sites, the sod is often interrupted. Seldom has brome spread to double the original seeded area. The low 
brome ratings resulted when brome occupied only part of the plot but was averaged over the entire plot.

Tall oatgrass has spread widely by seed. Adjacent plots often have heavier stands than the seeded plots. In two studies on the Davis Creek watershed, tall oatgrass was seeded on six of 120 plots. It now occupies 60 plots with an average rating of 5.6. It also occurs in smaller amounts on 30 additional plots. Its spread is most rapid on disturbed areas; however, it is growing well on some areas with good stands of big sagebrush and other native vegetation.

In general, the best seedling stands were in the bottom of the terrace trenches. Next best were stands on the loose soil of the fill, followed by stands on the cut. If melting snows or spring rains filled the trenches for extended periods, the young seedlings in the bottom of the furrow were killed, and spotty stands resulted. As plants matured, they were able to withstand flooding. After 32 years the best seeded and naturally revegetated stands are in the furrow, the fill, and the cut in the order named. However, species have spread and there are often good stands on the undisturbed area between terraces.

In 1938 the 1-, 2-, 3-, and 4-year-old stands of seeded grass mixtures yielded 77, 294, 840, and 2,644 lb./acre, air-dry, respectively. Yields of the three most successful seeded species and the two most abundant native grasses in 1971 are shown in Table 2.

Based on these studies, smooth brome, tall oatgrass, and intermediate wheatgrass are the best species for long-time stands and have out-yielded native species. These three grasses are recommended for high elevations in Utah and Idaho by Plummer et al. (1955), Hull et al. (1962), and Hull and Holmgren (1964). The tests were not fair for slender wheatgrass because the plains strain was used. This is shortlived and does not reseed itself on these areas. Other possible adapted species, such as meadow foxtail (Alopecurus pratensis), were not readily available for testing when these seedings were made.

Native species have increased on all areas. Where terraces were close to aspen, the formerly closely-cropped aspen sprouts were released and aspen trees up to five inches in diameter are growing in the trenches. Dense stands of big sagebrush account for $70 \%$ of the vegetation on some areas (Fig. 1). Sagebrush does especially well on the outer terrace bank. Two needlegrasses, columbia and letter-
Table 2. Production (lb./acre air-dry) of seeded and native grasses at 4 locations on the Davis County watershed, 1971.

\begin{tabular}{lcccc}
\hline \hline Species & $\begin{array}{c}\text { Davis } \\
\text { Creek }\end{array}$ & $\begin{array}{c}\text { Ford } \\
\text { Creek }\end{array}$ & $\begin{array}{c}\text { Parrish } \\
\text { Creek }\end{array}$ & $\begin{array}{c}\text { Farmington } \\
\text { Creek }\end{array}$ \\
\hline $\begin{array}{l}\text { Seeded } \\
\quad \text { Smooth brome }\end{array}$ & 1625 & 2436 & 2170 & 3780 \\
$\quad \begin{array}{l}\text { Tall oatgrass } \\
\quad \begin{array}{l}\text { Intermediate wheatgrass } \\
\text { a }\end{array}\end{array}$ & $\begin{array}{c}\text { C } \\
\text { Native }\end{array}$ & - & - & 3720 \\
$\quad \begin{array}{l}\text { Slender wheatgrass } \\
\quad \text { Columbia and letterman }\end{array}$ & 1524 & 1484 & 1628 & 2179 \\
$\quad$ needlegrasses & 1204 & 924 & 921 & 1297 \\
\hline
\end{tabular}

${ }^{\text {a }}$ Seeded in 1941 adjacent to experimental studies.

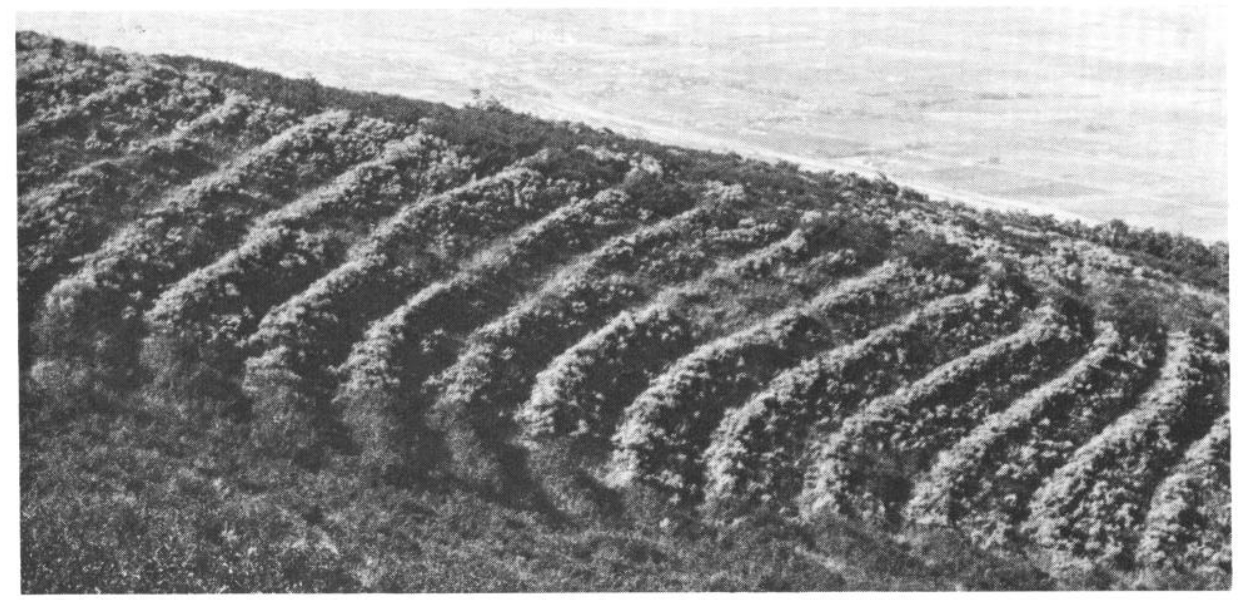

Fig. 1. General view of experimental seeding on the Davis Creek watershed. When terraced and seeded in the fall of 1936 and the spring of 1937, this area supported a sparse stand of perennial and annual weeds. Big sagebrush is now the dominant species. Smooth brome has an average rating of 8.7 and tall oatgrass 8.3 on three plots of each. Tall oatgrass has spread to 37 of the 60 plots on this site. The town of Bountiful is left center.

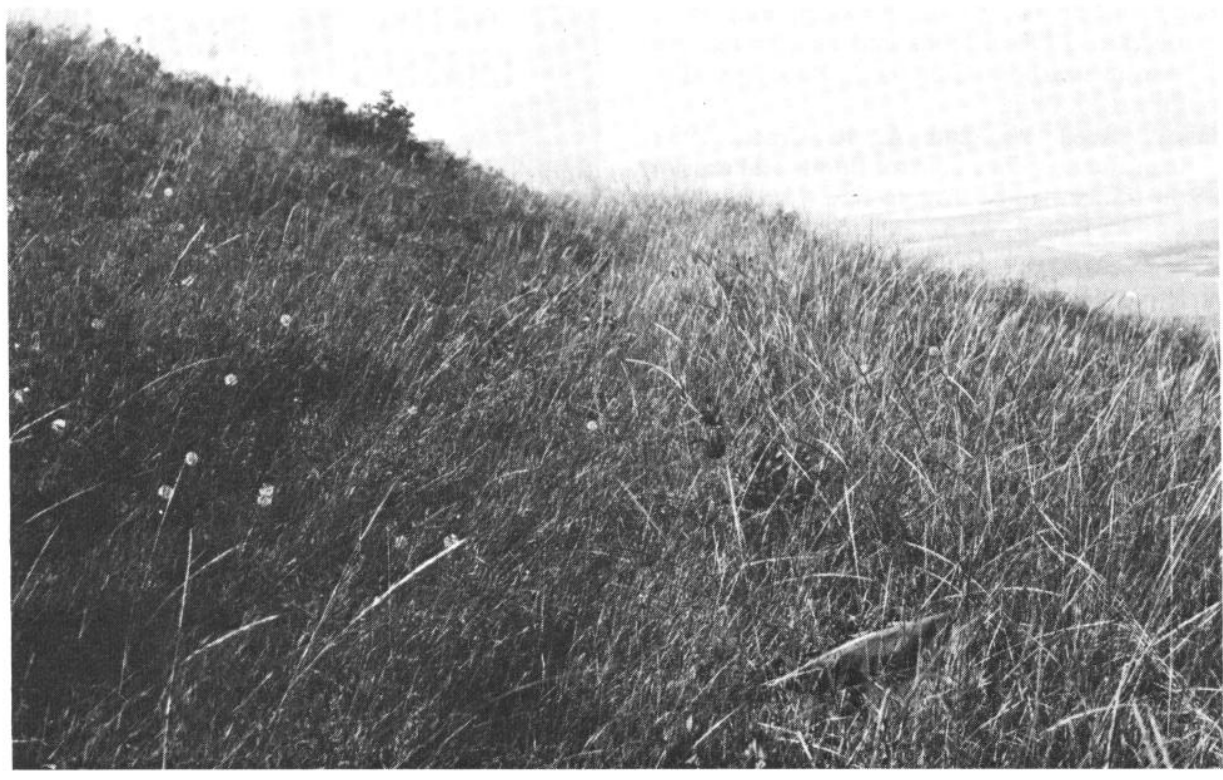

Fig. 2. This site had only scattered annual weeds when it was terraced and seeded in the fall of 1936. Native and seeded species, especially columbia needlegrass, are growing so well that it is difficult to see the terrace trench in the center of the photo. 
man, are present on all areas and sometimes comprise $50 \%$ of the vegetation (Fig. 2). Native slender wheatgrass and a great variety of perennial forbs are abundant on most areas. The estimated average percent cover of all native species on seeded areas follows:

\section{Species}

\section{\% Cover}

Forbes, including sedges and rushes

Sagebrush

Other shrubs, mainly snowberry

Needlegrasses

Other grasses, mainly slender wheatgrass

Trees, aspen, and chokecherry

Where seedings failed and native species did not reinvade terraced areas, there is considerable tarweed, knotweed, and other annuals. In such areas the terraces are partially filled and the outer banks are reduced in height by soil sloughing. Good stands of seeded and native vegetation have helped hold the soil and prevent filling of trenches or breakdown of the outer banks. With good stands, the gullies are healing, and there has been no disastrous runoff from these areas since they were terraced and seeded over 30 year ago (Fig 3). Some larger gullies which could not be treated now have good stands of reed canarygrass and smooth brome. These two rhizomatous seeded species along with native species are helping to stabilize these gullies.

\section{Literature Cited}

Bailey, Reed W., C. L. Forsling, and R. J. Becraft. 1934. Floods and accelerated erosion in northern Utah. U. S. Dep. Agr. Misc. Pub. 196. 22 p.

Bailey, Reed W., and A. R. Croft. 1937. Contour-trenches control floods and erosion on range lands. Emergency Consv. Work Forest. Pub. 4. 22 p.

Cannon, Sylvester Q., et al. 1931. Torrential floods in northern Utah. Utah State Univ. Agr. Exp. Sta. Circ. 92. 51 p.

Hull, A. C. Jr., and Ralph C. Holmgren. 1964. Seeding southern Idaho rangelands. Intermountain Forest and Range Exp. Sta. Res. Paper INT-10. 32 p.

Hull, A. C. Jr., A. T. Bleak, R. E. Eckert, Dillard Gates, Fred Gomm, and G. J. Klomp. 1962. Seeding depleted mountain rangelands. Agr. Res. Serv., U. S. Dep. Agr. CR-5-61. $10 \mathrm{p}$.

Marston, R. B. 1958. The Davis County experimental watershed story. Intermountain Forest and Range Exp. Sta. Forest Serv., U. S. Dep. Agr., Ogden, Utah. 37 p. (Mimeo.)

Plummer, A. Perry, A. C. Hull, Jr., George Stewart, and Joseph H. Robertson. 1955. Seeding rangelands in Utah, Nevada, southern Idaho, and western Wyoming. U. S. Dep. Agr. Agr. Handbook 71.73 p.

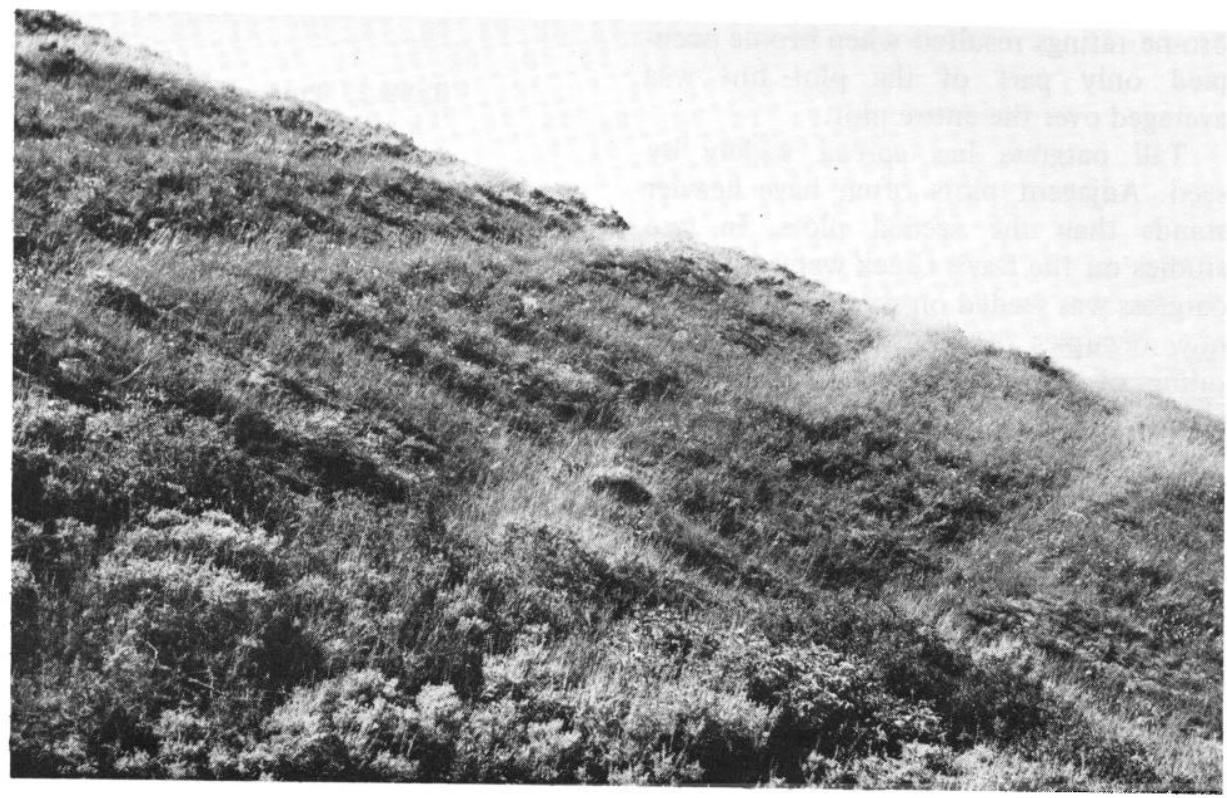

Fig. 3. Gullies from the 1923-30 floods may still be seen in this experimental seeding on the Davis Creek drainage. This site was raw and bare with no vegetation when it was terraced and seeded in fall, 1936, and spring, 1937. A good stand of smooth brome and tall oatgrass with some native species are holding the soil, and there has been no appreciable soil erosion since 1936. Photographed in 1971.

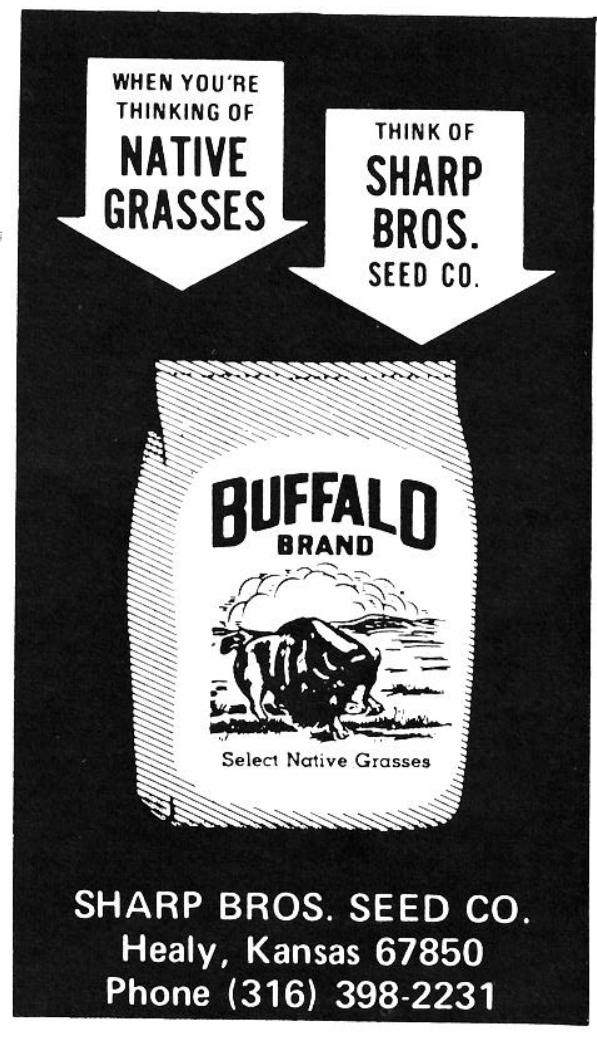

\section{Newfords}

New range cattle blood for maximum hybrid vigor!

Good range management means more forage, so be sure of getting the most in animal maintenance and growth from proper utilization of this renewable resource. In many tests on many ranges Newfords are proven producers of more pounds of beef per cow bred.

Newfords have consumer carcasses, developed from 32 years of using US Range Station Line I plus other superior inheritance traits.

Write for brochures on semen availability and Second Newford Seedstock Sale, May 7, 1973.

\section{HUGHES NEWFORD CO. BOX 158}

STANFORD, MONTANA 59479

Our 81 st year selling grass 